\title{
MAPK9 wt Allele
}

National Cancer Institute

\section{Source}

National Cancer Institute. MAPK9 wt Allele. NCI Thesaurus. Code C51260.

Human MAPK9 wild-type allele is located within $5 q 35$ and is approximately $45 \mathrm{~kb}$ in length.

This allele, which encodes mitogen-activated protein kinase 9 protein, is involved in the activation of nuclear transcription factors in response to environmental stress and pro-

inflammatory cytokines, stabilization of the p53 tumor suppressor protein and differentiation of T-helper cells. 